\title{
Spinal dysraphism: genetic relation to neural tube malformations
}

\author{
C. O. CARTER, K. A. EVANS, and K. TILL* \\ From MRC Clinical Genetics Unit, Institute of Child Health, 30 Guilford Street, London WC1N 1EH
}

Summary. The families of 207 index patients treated for spinal dysraphism at The Hospital for Sick Children were studied to discover whether the condition was aetiologically related to the classical neural tube malformations-spina bifida cystica and anencephaly. The index patients had all had a tethered conus medullaris and one or more of a variety of anomalies of the spinal cord, vertebrae, or skin overlying the vertebral column.

Of 364 sibs of index patients, 9 had anencephaly and 6 spina bifida cystica, a proproportion of $4.12 \%$. This approximates to the proportion of sibs affected by neural tube malformations in the London region when the index patients themselves have spina bifida or anencephaly.

It is, therefore, appropriate that the mothers of children with spinal dysraphism should be offered prenatal screening for neural tube malformations.

Spinal dysraphism is a term used by neurosurgeons to include patients with a conus which has an abnormal attachment to neighbouring structures and which may be elongated, together with one or more of a variety of anomalies of the spinal cord, vertebrae, and skin (Till, 1969; James and Lassman, 1972).

Family studies have shown links between anencephaly, iniencephaly, encephalocele, and spina bifida cystica (Record and McKeown, 1950; Carter, David, and Laurence, 1968; Carter and Evans, 1973a). Reports of radiographic studies on parents and sibs of patients with spina bifida and anencephaly (Laurence et al, 1971; Gardner, Alexander, and Veale, 1974) showed a link with spina bifida occulta provided that either the neural arches of several vertebrae were affected or that the defect of the arch of one vertebra was large. More recently it has been shown (Wynne Davies, 1975) that congenital scoliosis caused by multiple defects of the vertebral bodies, with or without spina bifida occulta, is also aetiologically related to the classical neural tube malformations. Such congenital scoliosis is often associated with a split of the spinal cord (Keim and Greene, 1973).

On the other hand, it has been commonly be-

\footnotetext{
Received 5 January 1976.

* Present address: The Hospital for Sick Children, Great Ormond Street, London WC1N 3JH.
}

lieved by neurosurgeons that there is no evidence that, 'any form of dysraphism is even partly genetically determined' (Williams, 1973) and no link with the neural tube malformations. Nevertheless, experience of individual families, for example a woman with spinal dysraphism who had two children with spina bifida cystica, as well as the occasional occurrence of spinal dysraphism among the sibs of patients with classical neural tube malformations led us to suspect an association. (These families are not included in the following study.)

These suspicions were supported by the findings from the careful necropsy studies of Emery and Lendon (1973) on children who have died from myelomeningocele. Their findings have shown that, in the majority, at or above the site of the main lesion it is not unusual to find a split cord, intra- or extradural lipomata, and vertebral body anomalies.

We, therefore, undertook a family study of spinal dysraphism based on a consecutive series of 207 index patients treated surgically by one of us (K.T.).

\section{Subjects and methods}

The initial consecutive series included 251 patients. All patients had an abnormal conus and, in addition, had one or more further anomalies, either of:

(1) the cord and meninges-diastemetomyelia, internal meningocoele, dermoid cyst, intradural, or extradural lipomata; 
(2) the skeleton-spina bifida occulta involving more than one vertebra, vertebral body anomalies, fused posterior elements, widening of the vertebral canal;

(3) the skin over the spine-hairy patch, pigmented or capillary naevus, dermal sinus, dimple, lipoma, congenital scarring;

(4) signs of neurological damage in the lower limbs, such as shortening of the foot or leg, talipes equinovarus, anaesthesia of the foot, and urinary incontinence.

Of the total of 251 patients, 44 were excluded: 19 had spina bifida cystica and in these the link with neural tube malformations is evident; 9 were abroad; 4 were adopted; 2 were not traced; 10 families refused to take part in the study. The remaining 207 are the index patients for the family study.

The families of the index patients were visited, usually in their own homes, and family histories obtained, paying special attention to possible instances of neural tube malformations in relatives. Such malformations were documented in all cases, except for 2 anencephalics (a sib and a cousin) both born at home before 1961 (the year in which the causes of stillbirth were first registered), and spina bifida in a cousin living in Ireland. In these 3 instances the mothers' convincing stories were accepted as reliable without documentary confirmation.

\section{Findings}

Sex ratio: Of the total series of 232 index patients (excluding the 19 with spina bifida cystica), 68 were boys and 164 girls, a sex ratio of 0.41 .

The family findings based on the pedigrees obtained for the 207 index patients are listed in the Appendix and summarized below.

\section{Spina bifida and anencephaly in relatives}

Parents. One father and one mother had had a meningocele repaired in childhood.

Sibs. The information on sibs is summarized in Table 1. Of a total of 364 live and stillborn sibs, 6 had spina bifida cystica (including 2 with encephalocele) and $9 \mathrm{had}$ anencephaly, that is $4.12 \%$ had a neural tube malformation.
TABLE I

SPINAL DYSRAPHISM: SIBS OF INDEX PATIENTS SHOWING THOSE AFFECTED BY SPINA BIFIDA (S) AND ANENCEPHALY (A)

\begin{tabular}{|c|c|c|c|}
\hline $\begin{array}{l}\text { Index } \\
\text { Patients }\end{array}$ & Brothers & Sisters & Total \\
\hline $\begin{array}{lr}\text { Male } & 59 \\
\text { Female } & 148\end{array}$ & 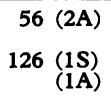 & 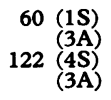 & $\begin{array}{rr}116 & (1 S) \\
(5 A) \\
248(5 S) \\
(4 A)\end{array}$ \\
\hline Total 207 & 182 (1S) & $182 \begin{array}{r}(5 S) \\
(6 A)\end{array}$ & $364 \begin{array}{r}(6 S) \\
(9 A)\end{array}$ \\
\hline
\end{tabular}

Of these 15 affected sibs, 9 were stillborn. There were an additional 10 stillborn sibs, and there was insufficient information to exclude neural tube malformation in 7 of them. The expected total stillbirths in a series of 364 total births is about 6 .

Half-sibs. The information on half-sibs is shown in Table II. Of a total of 43 half-sibs, 1 had spina bifida and 2 had anencephaly, a proportion of $6.98 \%$.

Nephews and nieces and cousins. The information on nephews and nieces is shown in Table III and on first cousins in Table IV. Of 38 nephews and nieces, 2 , both children of sisters of index patients, had anencephaly; 3 of 1072 paternal first cousins, and 11 of 1015 maternal first cousins, had neural tube malformations.

\section{Spinal dysraphism in relatives}

No attempt was made to document all cases of possible dysraphism in relatives, but it is noteworthy that 4 sibs (Cases 126, 130, and 164), 1 paternal and 4 maternal cousins (Cases 119, 38, 45, 94, and 151), had been treated operatively for spinal dyraphism. These are shown in the Appendix.

Individual families. Two pedigrees from the series illustrating the concurrence within families of

TABLE II

SPINAL DYSRAPHISM: HALF-SIBS OF INDEX PATIENTS SHOWING THOSE AFFECTED BY SPINA BIFIDA (S) AND ANENCEPHALY (A)

\begin{tabular}{|c|c|c|c|c|c|}
\hline \multirow{2}{*}{$\begin{array}{l}\text { Index } \\
\text { Patients }\end{array}$} & \multicolumn{2}{|c|}{ Paternal } & \multicolumn{2}{|c|}{ Maternal } & \multirow{2}{*}{ Total } \\
\hline & Brothers & Sisters & Brothers & Sisters & \\
\hline $\begin{array}{lr}\text { Male } & 59 \\
\text { Female } & 148\end{array}$ & $\begin{array}{l}1 \\
3\end{array}$ & $\begin{array}{l}4 \\
7 \text { (1S) }\end{array}$ & $\begin{array}{l}5 \\
11(1 \mathrm{~A})\end{array}$ & $\begin{array}{l}4 \\
8(1 \mathrm{~A})\end{array}$ & $\begin{array}{l}14 \\
29(1 S)\end{array}$ \\
\hline Total 207 & 4 & 11 (1S) & $16(1 \mathrm{~A})$ & $12(1 \mathrm{~A})$ & $43 \begin{array}{l}(1 S) \\
(2 A)\end{array}$ \\
\hline
\end{tabular}


TABLE III

SPINAL DYSRAPHISM: NEPHEWS AND NIECES OF INDEX PATIENTS SHOWING THOSE AFFECTED BY SPINA BIFIDA (S) AND ANENCEPHALY (A)

\begin{tabular}{|c|c|c|c|c|c|}
\hline \multirow{2}{*}{$\begin{array}{c}\text { Index } \\
\text { Patients }\end{array}$} & \multicolumn{2}{|c|}{ Brothers } & \multicolumn{2}{|c|}{ Sisters } & \multirow[t]{2}{*}{ Total } \\
\hline & Sons & Daughters & Sons & Daughters & \\
\hline $\begin{array}{lr}\text { Male } & 59 \\
\text { Female } & 148\end{array}$ & $\overline{6}$ & $\begin{array}{l}4 \\
4\end{array}$ & $11 \overline{(1 A)}$ & $12^{1(\mathrm{~A})}$ & $\begin{array}{r}5 \text { (1A) } \\
33 \text { (1A) }\end{array}$ \\
\hline Total 207 & 6 & 8 & $11(1 \mathrm{~A})$ & $13(1 \mathrm{~A})$ & 38 (2A) \\
\hline
\end{tabular}

TABLE IV

SPINAL DYSRAPHISM: COUSINS OF INDEX PATIENTS SHOWING THOSE AFFECTED BY SPINA BIFIDA (S) AND ANENCEPHALY (A)

\begin{tabular}{|c|c|c|c|c|c|c|c|c|c|c|}
\hline \multirow{3}{*}{\multicolumn{2}{|c|}{$\begin{array}{l}\text { Index } \\
\text { Patients }\end{array}$}} & \multicolumn{4}{|c|}{ Fathers } & \multicolumn{4}{|c|}{ Mothers } & \multirow{3}{*}{ Total } \\
\hline & & \multicolumn{2}{|c|}{ Brothers } & \multicolumn{2}{|c|}{ Sisters } & \multicolumn{2}{|c|}{ Brothers } & \multicolumn{2}{|c|}{ Sisters } & \\
\hline & & Sons & Daughters & Sons & Daughters & Sons & Daughters & Sons & Daughters & \\
\hline Male & 59 & 83 (1S) & 67 & 84 & 88 & 93 & $93(2 A)$ & 75 & $62(3 S)$ & 645 (4S) \\
\hline Female & 148 & 181 & 169 & $207(2 S)$ & 193 & 163 & $181(3 A)$ & $185(1 S)$ & $163 \stackrel{(1 \mathrm{~S})}{(1 \mathrm{~A})}$ & $1442(4)$ \\
\hline Total & 207 & $264(1 S)$ & 236 & $291(2 S)$ & 281 & 256 & $274(5 A)$ & $260(1 S)$ & $225\left(\begin{array}{l}(4 \mathrm{~S}) \\
(1 \mathrm{~A})\end{array}\right.$ & $2087 \begin{array}{l}(8 S) \\
(6 A)\end{array}$ \\
\hline \multicolumn{6}{|c|}{$1072(3 S)$} & \multicolumn{5}{|c|}{$1015\left(\begin{array}{l}(5 S) \\
(6 A)\end{array}\right.$} \\
\hline
\end{tabular}

neural tube malformation and spinal dysraphism are shown in the Fig.

Maternal age and birth order. Studies of maternal age and birth order are of limited value in a series of patients who were born over a period of 27

Fomily 180

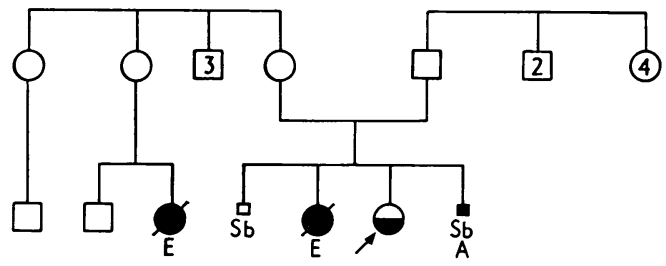

Fomily 10

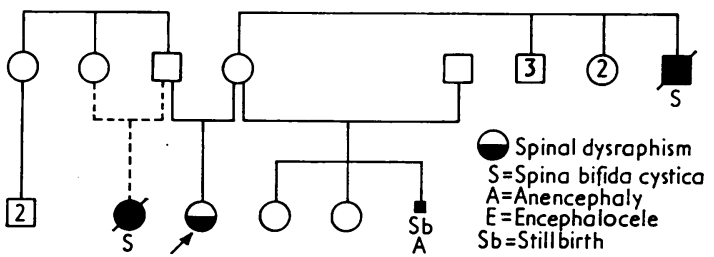

FIG. Pedigrees shcwing spinal dysraphism and neural malformations within the same family. years (1946 to 1972) drawn from a special clinic and from widely different parts of the country. The mean maternal age was 26.5 and the mean birth order (excluding previous stillbirths) was 1.9.

TABLE V

MATERNAL AGE (FOR LIVEBORN LEGITIMATE BIRTHS) COMPARED WITH THOSE FOR ENGLAND AND WALES 1963 REGISTRAR GENERAL'S FIGURES-TABLE HH

\begin{tabular}{l|l|l|l|l|l|l|l}
\hline & \multicolumn{5}{|c|}{ Maternal Age } & Total \\
\cline { 2 - 7 } & $14-19$ & $20-24$ & $25-29$ & $30-34$ & $35-39$ & $40+$ & \\
\hline Observed & 15 & 75 & 62 & 29 & 17 & 2 & 200 \\
Expected & 14.37 & 63.55 & 63.69 & 36.44 & 16.96 & 4.98 & \\
\hline
\end{tabular}

TABLE VI

BIRTH ORDER (FOR LIVEBORN LEGITIMATE BIRTHS) COMPARED WITH THOSE FOR ENGLAND AND WALES 1963 REGISTRAR GENERAL'S FIGURESTABLE HH

\begin{tabular}{l|c|c|c|c|c|c|c}
\hline & \multicolumn{6}{|c}{ Number of Children Born Before Index Patient } \\
\cline { 2 - 8 } & 0 & 1 & 2 & 3 & 4 & $5+$ & Total \\
\hline Observed & 109 & 45 & 27 & 7 & 8 & 4 & \multirow{2}{*}{200} \\
Expected & 72.3 & 61.7 & 33.3 & 16.1 & 7.8 & 8.7 & \\
\hline
\end{tabular}


TABLE VII

COMPARISON OF SIBS AFFECTED BY SPINA BIFIDA AND

ANENCEPHALY IN STUDY OF SPINAL DYSRAPHISM, AND TWO STUDIES OF NEURAL TUBE MALFORMATIONS

\begin{tabular}{|c|c|c|c|c|c|}
\hline \multicolumn{2}{|l|}{ Index Patients } & \multirow{2}{*}{$\begin{array}{c}\text { Total Sibs } \\
364\end{array}$} & \multicolumn{2}{|c|}{$\begin{array}{l}\text { Sibs With: } \\
\text { Spina } \\
\text { Bifida Anencephaly }\end{array}$} & \multirow{2}{*}{$\begin{array}{c}\begin{array}{c}\text { Proportion } \\
\text { Affected } \\
(\%)\end{array} \\
4.12\end{array}$} \\
\hline Spinal dysraphism & 207 & & 6 & 9 & \\
\hline $\begin{array}{l}\text { Classical neural } \\
\text { tube malformation } \\
\text { London 1965-1968: } \\
\text { Spina bifida } \\
\text { Anencephaly }\end{array}$ & $\begin{array}{l}478 \\
361\end{array}$ & $\begin{array}{l}730 \\
754\end{array}$ & $\begin{array}{l}13 \\
17\end{array}$ & $\left.\begin{array}{l}12 \\
24\end{array}\right\}$ & 4.45 \\
\hline $\begin{array}{l}\text { S. Wales 1956-1962: } \\
\text { Spina bifida } \\
\text { Anencephaly }\end{array}$ & $\begin{array}{l}423 \\
361\end{array}$ & $\begin{array}{l}854 \\
708\end{array}$ & $\begin{array}{l}32 \\
13\end{array}$ & $\left.\begin{array}{l}20 \\
16\end{array}\right\}$ & 5.18 \\
\hline
\end{tabular}

These are probably not exceptional, but it is noteworthy that 109 of the 200 legitimate patients, $54.5 \%$, were first born when the expected proportion from the general distribution for England and Wales would not have been more than $40 \%$.

The distribution of maternal age and birth order is shown in Tables V and VI and compared with the expected number from the distribution in England and Wales in 1963.

\section{Discussion}

The main finding that 15 of $364(4.12 \%)$ sibs have a neural tube malformation leaves little doubt that this group of anomalies labelled 'spinal dysraphism' is aetiologically related to the classical neural tube malformations, anencephaly and myelomeningocele. With these classical malformations the proportion of sibs affected was $5.18 \%$ in a South Wales series (Carter et al, 1968) where the birth frequency was $0.77 \%$, and $4.45 \%$ in a London series (Carter and Evans, 1973b) where the birth frequency was $0.30 \%$. The comparison with this present series is shown in Table VII. The proportion of sibs with classical neural tube malformation is similar when index patients have spinal dysraphism and when index patients have neural tube malformations.

Subdivision of the spinal dysraphism index patients according to the presence or absence of spina bifida occulta involving several affected vertebrae, or of cutaneous lesions, did not suggest any difference in the proportion of sibs affected.

The rather high proportion of half sibs and nieces and nephews affected with neural tube malformations is probably a chance small number effect, as it is appreciably higher than that found when index patients have classical neural tube malformations.

In cousins the finding of about a twofold increase over the expected proportion affected with neural tube malformations in maternal, though not paternal, cousins is similar to the findings in cousins of index patients with spina bifida and anencephaly. The difference between the proportion affected of maternal and paternal cousins probably only reflects more complete ascertainment on the maternal side.

The sex ratio of 0.41 is similar to that in James and Lassman's series, 0.37. It is lower than that found in spina bifida but similar to that found in anencephaly.

The excess of first born in this series is similar to that seen in most series of classical neural tube malformations. The absence of any maternal age effect is also seen in a more recent series of classical neural tube malformations (Carter and Evans, 1973a).

It appears that the classical neural tube malformations, spinal dysraphism, severe spina bifida occulta, and congenital scoliosis caused by vertebral anomalies are a genetically and embryologically related group of malformations. This has practical implications for prenatal diagnosis. The parents of children with spinal dysraphism should be offered the opportunity of prenatal screening for neural tube malformations. The patients themselves, on the analogy of the risk of neural tube malformations in the offspring of patients who had spina bifida cystica (Carter and Evans, 1973b) should, when the time is right, be alerted to the risk and to the availability of prenatal diagnosis. The families in the series have been warned either directly or through their family doctor.

We are grateful to Mrs Joan Warren who shared the family visiting with K.E. and to Miss M. Mehta of the Royal National Orthopaedic Hospital who kindly examined several relatives and scrutinized medical records. 


\section{REFERENCES}

Carter, C. O., David, P. A., and Laurence, K. M. (1968). A family study of major central nervous system malformation in South Wales. Fournal of Medical Genetics, 5, 81-106.

Carter, C. O., and Evans, K. A. (1973a). Spina bifida and anencephalus in Greater London. Fournal of Medical Genetics, 10, 209234.

Carter, C. O. and Evans, K. A. (1973b). Children of adult survivors with spina bifida cystics. Lancet, 2, 924-926.

Emery, J. L. and Lendon, R. G. (1973). The local cord lesion in neurospinal dysraphism (meningomyelocele). Fournal of Patho$\log y, 110,83-96$.

Gardner, R. J. M., Alexander, C., and Veale, A. M. O. (1974). Spina bifida occulta in the parents of offspring with neural tube defects. Fournal de Génétique Humaine, 22, 389-395.

James, M. and Lassman, L. P. (1972). Spinal Dysraphism. Butterworths, London.
Keim, H. A. and Greene, A. F. (1973). Diastematomyelia and scoliosis. Fournal of Bone and Foint Surgery, 55A, 1425-1435.

Laurence, K. M., Bligh, A. S., Evans, K. T., and Shurtleff, D. B. (1971). Vertebral abnormalities in parents and sibs of cases of spina bifida cystica, enencephalocoele, and anencephaly. In proceedings of the 13th International Congress of Paediatrics, V-2, 415.

Record, R. G. and McKeown, T. (1950). Congenital malformations of the central nervous system III Risks of malformation in sibs of malformed individuals. British fournal of Preventive and Social Medicine, 4, 217-220.

Till, K. (1969). Spinal dysraphism: a study of congenital malformations of the back. Developmental Medicine and Child Neurology, $10,471-478$.

Williams, B. (1973). The spinal cord in spinal dysraphism. Lancet, 2, 1034.

Wynne Davies, R. (1975). Congenital vertebral anomalies; aetiology and relationship to spina bifida cystica. Fournal of Medical Genetics, 12, 136-145.

\section{Appendix}

$M$, male; F, female; *, index patient, italics, spinal dysraphism; (S) spina bifida; (E) encephalocele;

(A) anencephaly; sb, stillbirth; [ ], twins

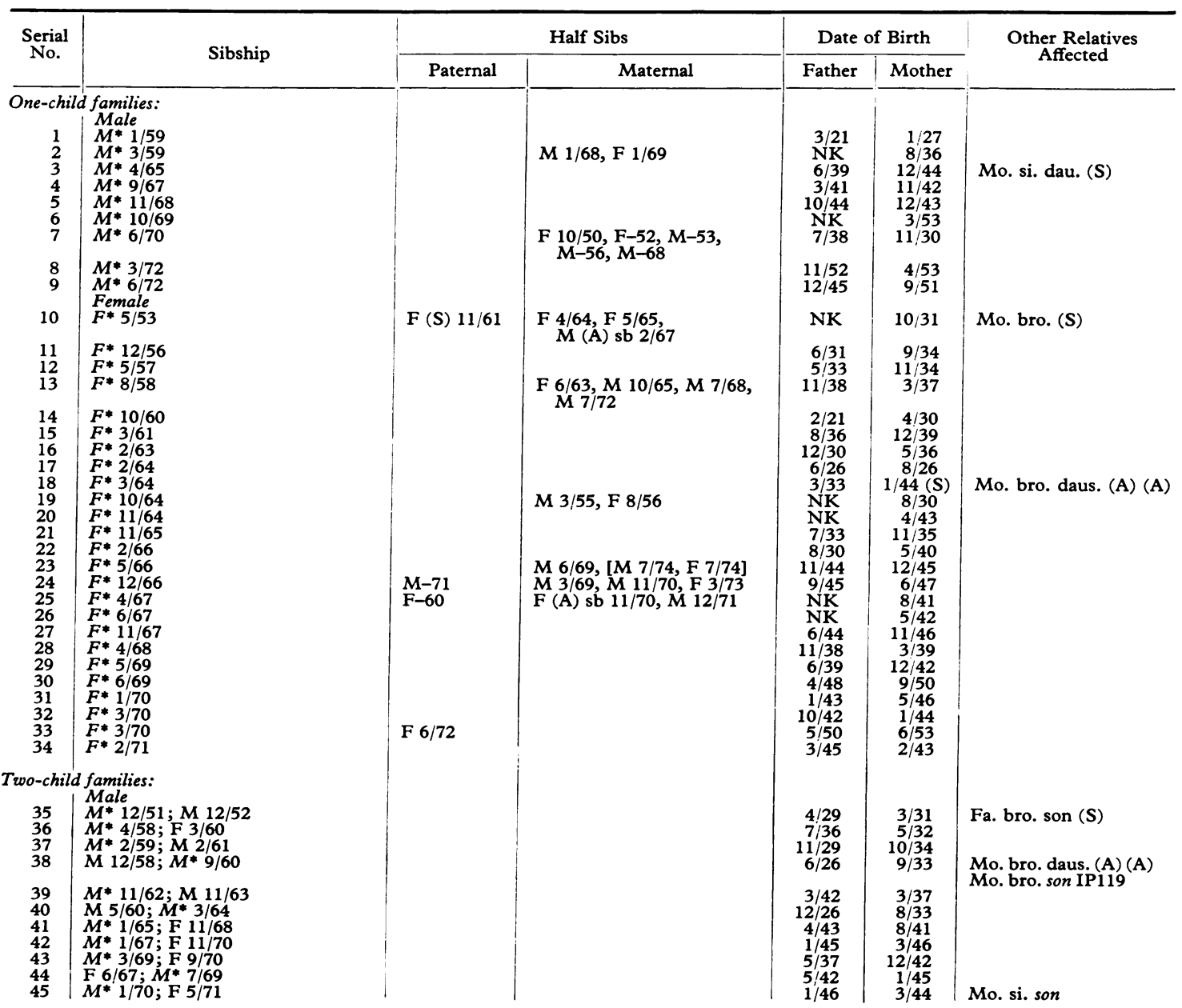


Appendix-continued

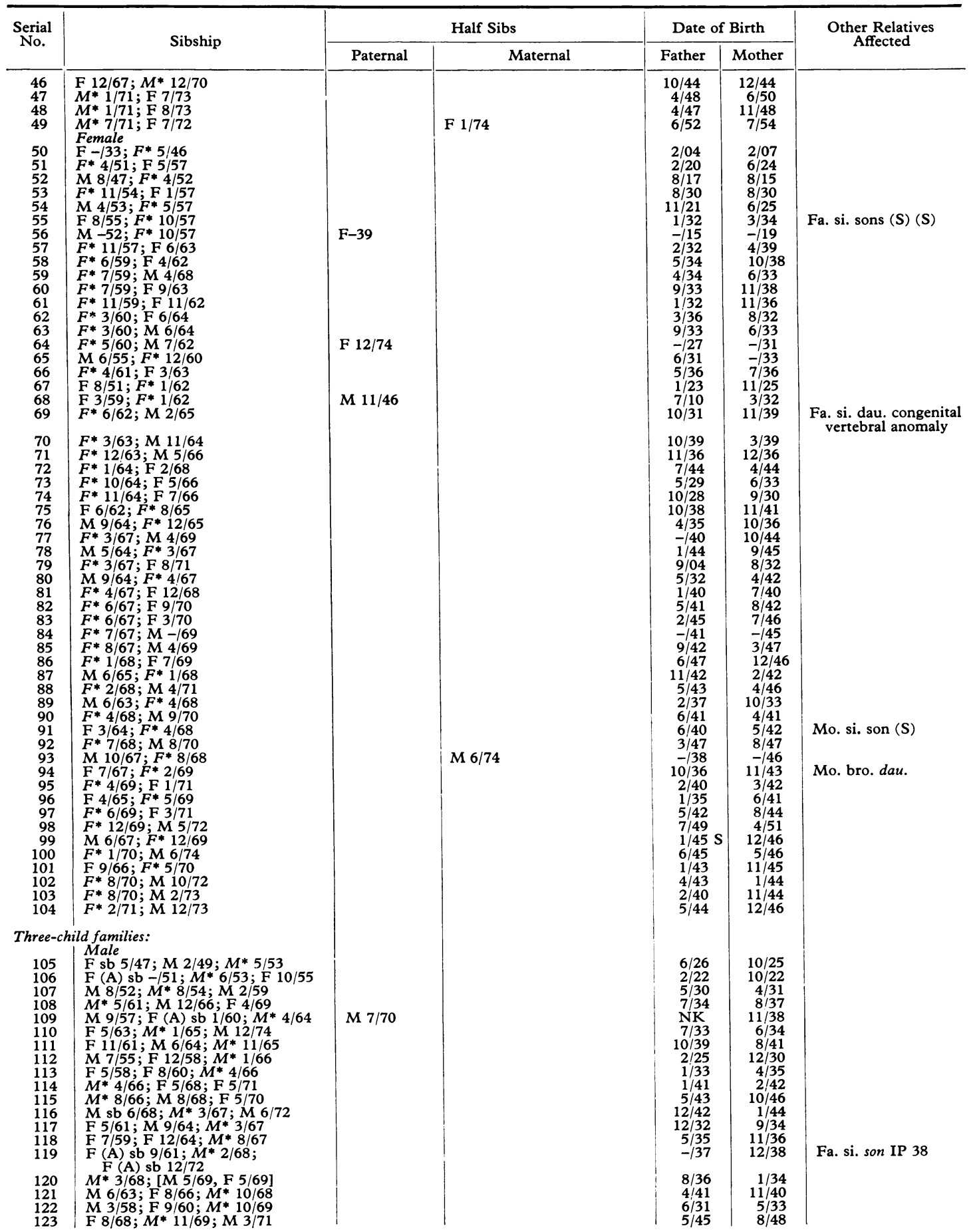


Appendix-continued

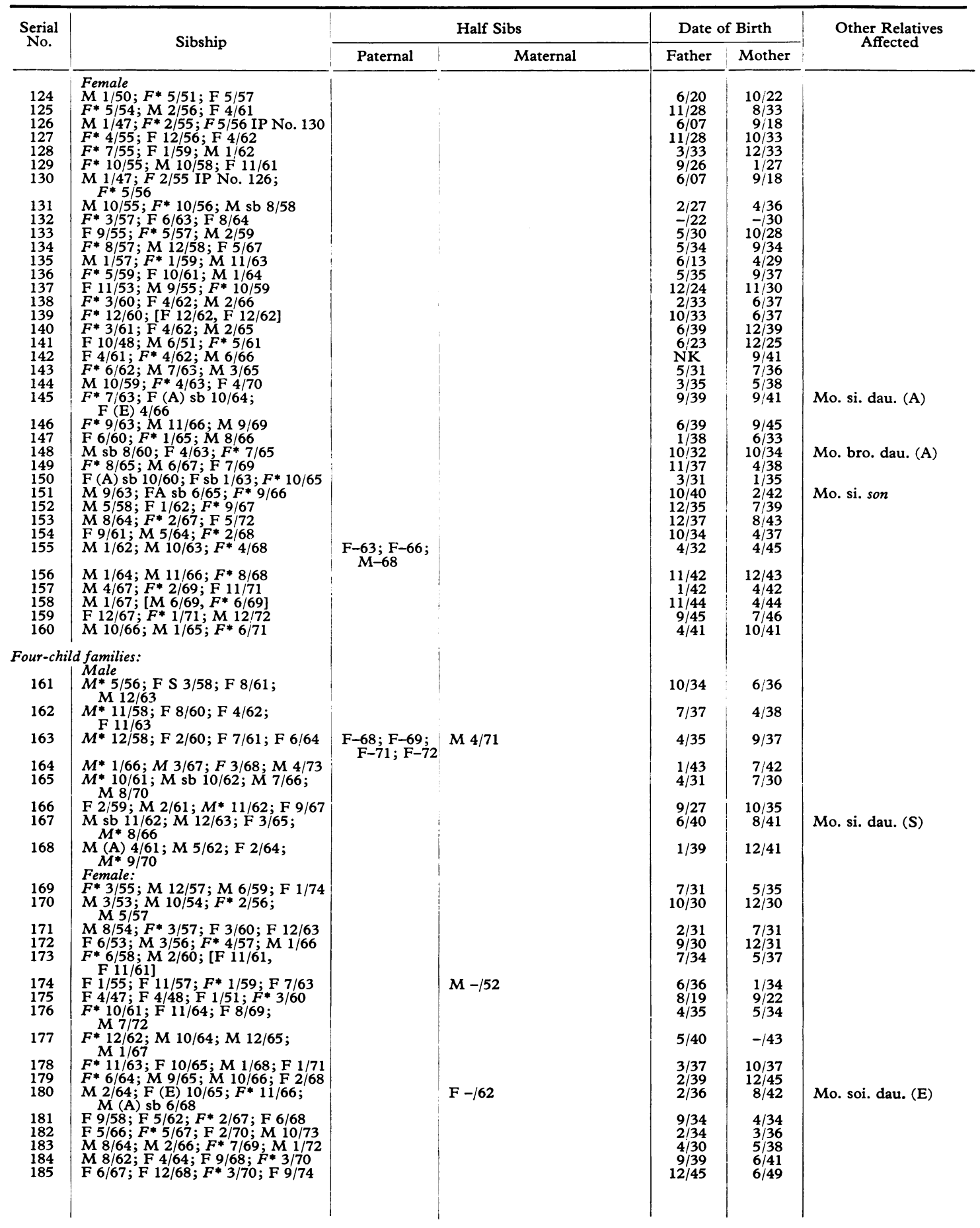


Appendix-continued

\begin{tabular}{|c|c|c|c|c|c|c|}
\hline \multirow{2}{*}{$\begin{array}{l}\text { Serial } \\
\text { No. }\end{array}$} & \multirow{2}{*}{ Sibship } & \multicolumn{2}{|c|}{ Half Sibs } & \multicolumn{2}{|c|}{ Date of Birth } & \multirow{2}{*}{$\begin{array}{l}\text { Other Relatives } \\
\text { Affected }\end{array}$} \\
\hline & & Paternal & Maternal & Father & Mother & \\
\hline \multicolumn{7}{|c|}{ Five-child families: } \\
\hline 186 & $\begin{array}{l}M * 5 / 58 ; M 10 / 59 ; M ~ 5 / 62 ; \\
\text { F } 10 / 63 ; \text { F 8/66; }\end{array}$ & & & $7 / 37$ & $11 / 39$ & Mo. si. dau. (S) \\
\hline 187 & $\begin{array}{l}M * 1 / 60 ; \mathrm{F} 1 / 61 ; M 4 / 63 ; \\
M 9 / 64 ; \mathrm{F} 6 / 66\end{array}$ & & & $9 / 36$ & $5 / 37$ & \\
\hline 188 & $\begin{array}{l}\text { F } 5 / 58 ; M 6 / 60 ; M^{*} 1 / 62 ; \\
M 6 / 64 ; F 1 / 69\end{array}$ & & & $6 / 27$ & $4 / 35$ & \\
\hline 189 & $\begin{array}{l}\text { F } 3 / 57 ; M 2 / 59 ; M 12 / 60 \\
M^{*} 1 / 62 ; \text { F } 9 / 64\end{array}$ & & & $6 / 35$ & $6 / 35$ & \\
\hline 190 & $\begin{array}{l}\text { F } 12 / 57 ; M 12 / 58 ; M 7 / 62 ; \\
M 7 / 63 ; M * 10 / 65\end{array}$ & & & $8 / 36$ & NK & \\
\hline 191 & $\begin{array}{l}M 10 / 52 ; M 3 / 54 ; M 1 / 58 \\
M 2 / 68 ; M^{*} 2 / 70 \\
\text { Female }\end{array}$ & & & $12 / 29$ & $9 / 34$ & \\
\hline 192 & 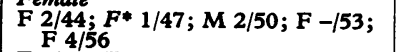 & & & $-/ 18$ & -120 & \\
\hline 193 & $\begin{array}{l}\mathrm{F}-/ 46 ; \mathrm{F} 3 / 47 ; \mathrm{M} \mathrm{sb}-154 ; \\
\mathrm{M} \mathrm{sb}-/ 55 ; F^{*} 3 / 56\end{array}$ & & & $10 / 22$ & $8 / 22$ & \\
\hline 194 & $\begin{array}{l}\text { M 11/47;M } 3 / 49 ; F(S) 10 / 50 ; \\
F(S) \text { sb }-156 ; F^{*} 2 / 62\end{array}$ & & & $7 / 23$ & $12 / 26$ & \\
\hline 195 & $M_{F * 11 / 60 ; F 2 ; 62 ; F} 2 / 63$ & & & $5 / 32$ & $7 / 42$ & \\
\hline 196 & $\begin{array}{l}\text { F } 9 / 50 ; M 8 / 52 ; M 6 / 54 \\
M 12 / 57 ; F^{*} 11 / 64\end{array}$ & & & $11 / 25$ & $10 / 31$ & \\
\hline 197 & $\begin{array}{l}\text { M } 5 / 53 ; M 11 / 54 ; F 8 / 57 \\
F 8 / 65 ; F^{*} 4 / 68\end{array}$ & & & $1 / 24$ & $6 / 31$ & Fa. bro. dau. dau. \\
\hline 198 & $\begin{array}{l}M 3 / 63 ; M 1 / 66 ; M 7 / 67 \\
F^{*} 1 / 69 ; F 12 / 70\end{array}$ & & & -131 & $10 / 39$ & \\
\hline 199 & F $3 / 57 ; F_{6 / 70} 6 / 58 ; F 12 / 61 ; M 12 / 63 ;$ & & & $5 / 32$ & $5 / 28$ & \\
\hline \multicolumn{7}{|c|}{ Six-child families } \\
\hline 200 & $\begin{array}{l}\text { M } 11 / 50 ; \mathrm{F} 2 / 56 ; M 8 / 57 ; \\
M 12 / 60 ; M^{*} 3 / 62 ; M 10 / 64 \\
\text { Female }\end{array}$ & & & $8 / 28$ & $12 / 30$ & \\
\hline 201 & $\begin{array}{l}\mathrm{F} 6 / 61 ; M 3 / 63 ; M \\
F^{*} 12 / 67 ; \mathrm{F} 6 / 69\end{array}$ & & & $1 / 33$ & $11 / 40$ & \\
\hline 202 & $\begin{array}{l}\text { F } 6 / 54 ; M 4 / 56 ; M 1 / 58 ; M 4 / 60 ; \\
\text { F } 1 / 61 ; F^{*} 3 / 68\end{array}$ & & & $11 / 27$ & $6 / 29$ & \\
\hline 203 & $\begin{array}{l}M \text { sb 5/51; } M 5 / 53 ; F 9 / 55 ; \\
M 4 / 58 ; M 12 / 62 ; F^{*} 1 / 69\end{array}$ & & & $3 / 20$ & $12 / 28$ & \\
\hline \multicolumn{7}{|c|}{ Seven-child families } \\
\hline 204 & $\begin{array}{l}\text { Female } \\
\mathrm{M}-/ 45 ; \mathrm{F}-/ 48 ; \mathrm{F}-/ 49 ; \mathrm{F}-151 ;\end{array}$ & & & $2 / 18$ & $2 / 21$ & $\begin{array}{l}\text { † Congenital vertebral } \\
\text { anomaly } \\
\text { Si. son }(A)\end{array}$ \\
\hline \multicolumn{7}{|c|}{ Eight-child families: } \\
\hline 205 & $\begin{array}{l}\text { M 1/52; F 3/54; F*3/56; } \\
M 10 / 57 ; F \text { 10/59; F 11/60; } \\
M 2 / 67 ; M 3 / 69\end{array}$ & & & $12 / 29$ & $3 / 36$ & \\
\hline 206 & $\begin{array}{l}\text { F } 6 / 65 ; M(S) 7 / 66 ; F 10 / 67 \\
F 11 / 68 ; M 3 / 71 ; F^{*} 4 / 72 ; \\
\text { F } 8 / 73 ; M 8 / 74\end{array}$ & & & $8 / 16$ & $8 / 39$ & \\
\hline \multicolumn{7}{|c|}{ Ten-child families: } \\
\hline 207 & $\begin{array}{l}\text { M 9/47; M 4/49; F 9/51; F 7/53; } \\
M \text { 3/55; F 6/57; F 7/59; } \\
M^{*} 6 / 62 ; \text { F 3/65; F 10/69 }\end{array}$ & & & $7 / 20$ & $9 / 28$ & Si. dau. (A) \\
\hline
\end{tabular}

